\title{
The Australian-Asian Connection: From AlfRed DeAKin to JoHn Howard
}

\section{Laksiri Jayasuriya}

University of Western Australia

\section{Introduction: Contextualizing Australia in Asia}

Several commentators have seized upon Australia's recent entry to the inner sanctum of East Asian Summit as a turning point in Australia's relationship with is regional neighbours. This goes to the heart of what I have termed the 'Australian-Asian Connection', or as others have called it, the Asian Engagement or Enmeshment. We indeed have come a long way since the historian La Nauze dismissed Australia's proximity to Asia as something for the future (Walker 2003) As we ponder the significance of joining the East Asian Summit, many questions come to mind: does this signify a radical change in Australia's view of itself? Is this the answer or a clue to the critical question whether Australia sees itself as an 'Asian nation' with a firm link to an Asian regional hegemon, or that Australia now embraces more firmly a duality - i.e., as an 'Asian nation as well as a European nation' (Collins 1985, 391). If, indeed there has been a change in how we comprehend the Australian-Asian connection, what underlies this sudden embrace of an 'Asian future' by none other than John Howard who in the past was forthright in his criticism of the regional policies in the Hawke and Keating era $\mathrm{h}$ (Dalrymple 2003).

This becomes a perplexing query, particularly when one recalls that Foreign Minister Downer has stated that Australia had no wish to be part of a new regionalism such as that portrayed by Mahathir and others. Downer went on to describe this as a form of 'cultural regionalism' which Australia rejects. By contrast he identified a 'Practical Regionalism' as the model to which Australia was committed. The difference between these forms of regionalism was that one is built on 'commonalities of history, of mutual cultural identity', and the other strictly on the mutual benefits of cooperation in the pursuit of common objectives of countries drawn together on the pursuit of mutual objectives.

In this context, does Australia's not just willingness, but even eagerness, to be a member of the East Asian Regional conclave signify a preparedness on the part of Australia to 
jettison its past and accommodate itself to the presumed cultural identity of this regional grouping as an expression of 'cultural regionalism'? But, as I shall argue a 'practical regionalism' is not possible without understanding and acknowledging how this plays out in the very 'unpractical' practices of Australian citizenship and identity.

But how does Australia see itself as a nation after a hundred years since gaining its independence from being under the tutelage of its colonial masters? This is central to how we begin to comprehend the 'Australian-Asian' connection when looked at from the Australian point of view. I propose to address just this issue by focusing on the question of how Australia sees itself as nation, its sense of nationhood vis a vis ' others', in particular her immediate neighbours. ${ }^{1}$ I suggest this is intimately linked to the peopling of Australia and the centrality of migration in the making of Australia as an independent nation, and perhaps more crucially, defining a sense of ‘who is an Australian'. As Jupp rightly observes, immigration has been 'a constant theme in Australian since 1788 but has often been curiously overlooked or under-stressed by historians’ (1986, 3).

Immigration, in particular anti Asian immigration was the dominant theme in the 'legendary decade' of the 1890s prior to Federation. This reached its high-water mark with the passage of the Immigration Restriction Act 1901, embodying the idea of a 'White Australia' at the time of Federation and the founding of the Commonwealth of Australia. Immigration as a policy of recruitment and settlement of new setters has ever since been a determining factor in the unfolding of an Australian sense of nationhood and national identity. A corollary to the White Australia policy was a defence and foreign policy built primarily around military and strategic security concerns symbolized by a 'Fortress Australia'. This was framed as a 'Forward Defence' policy strategy which saw Asia as the frontline for defending Australia (Crook 1970). It was a mix of policies around the core of restrictive immigration, defence, and external affairs that became identified as the White Australia policy. This was one of 'the two ring-fences [the other being protection] behind which economic and social life were pursued' (Hancock 1930, 77). Of these, immigration became the cardinal unifying principle of the fledgling nation, and 'the independent condition of every other policy' (Hancock 1930, 66). The cumulative effect of this

1. An alternative perspective on the Australian-Asian connection will be found in the recent work of the cultural theorists, e.g., Gilbert, Khoo \& Lo (200), and D’Cruz \& Steele (2003) and others who focus on 'Asia in Australia'. See also Bronowski (2003) for a well documented account of 'Australia in Asia', i.e., how Australia is perceived in the Region. 
overarching mix of national policy was to inculcate a 'racial consciousness', as a defining factor in 'imagining Australia'.

Considering the foundational role of a White Australia in the formation of nationhood, it has both created and defined over time the space between Australia and Asia. This has led to 'the celebrated tension between our history and geography' which is critical to understanding the contours of Australian foreign policy. But the burden of my argument is that the dilemma of 'history and geography' is not merely played out in the foreign policy arena, but is central to the very constitution of Australia's sense of her identity. In other words, history and geography is not taken to be a set of terms where history represents Australia and geography signifies Asia. Instead it is seen as being part of the constitutive narrative of the Australian political community and pivotal to framing citizenship in Australia. Such an approach I suggest allows for an understanding of current immigration policies, especially multiculturalism as an ideology of settlement, as being intrinsic - not external - to narratives about national identity. ${ }^{2}$ It is for this reason more than anything else that makes it difficult to have as Downer puts it a 'practical regionalism'.

After Federation and until the end of the Second World War, the legacy of Australia's origins - not just British, but also a European ancestry — have dominated all facets of the Australian landscape - political, economic and strategic. Indeed, these 'forces of history', largely a consequence of Australia being an 'anglo fragment' society ${ }^{3}$ (Hartz 1964), have fashioned much of existing international and domestic policies, not least those affecting Australia's relations with the countries of the Asian region. But, to understand the nature and significance of the impact of immigration on the Australian consciousness, nay, the Australian imagination, we need first and foremost, to adopt a broad brush historical approach to Australian immigration policy - of recruitment and settlement - to understand the tensions and conflicts inherent in what originally was a blatantly racist policy strategy (Markus 2001; Jayasuriya 1999; Jupp 1998).

2. In this context, see Roger Smith's (1997) notion of stories of peoplehood as a heuristic framework to explore some of the perennial dilemmas of Australian democracy and citizenship. According to Smith the politics of people building defines the basis on which the membership of the political community is to be determined.

3. Collins (1985) points out that for Hartz this was a 'radical fragment' in which a radical democracy overthrows an 'early whiggery and proceeds to define 'the national spirit in a bold but triumphant socialism’ (p. 165). 
The changing character of the Australian-Asian connection is vividly portrayed by the transformation that has taken place from the days of Alfred Deakin - one of the founding fathers of the Federation and one of the main architects of 'White Australia' - to that of John Howard, the architect of the making of a new Australian consciousness. This is the divide between a 'British Australia' and an 'Australian Australia' - a multicultural nation. The continuities and discontinuities of policy, thinking and vision between Deakin and Howard may well provide valuable insights into the complex dynamics of this evolving Australian-Asian connection. Above all, the legacy, nay ghosts, of a White Australia and British Australia, as a political narrative which continues to haunt all aspect of Australian public life.

\section{White Australia and the Deakin Legacy}

\section{Immigration and Federation}

Immigration, and in particular, Asian immigration, entered the public domain as a critical public policy issue mainly as a result of the substantial inflow of Chinese immigrants who came in the mid-nineteenth century to work in the gold mines of Victoria and later New South Wales. This led to anti Chinese immigration legislation in New South Wales and other colonies. The racial stereotypic categorisation as the 'Yellow Peril' - soon became generalised and covered all non European labour, such as Indian indentured labourers and also Melanesians (Kanakas) from the New Hebrides and Solomon Islands, located mainly in the mining and sugar cane industries of Queensland. The fear of economic competition from Asia was so great that racist doctrines of white supremacy became the rallying point for organised labour, and formed at this time one of the key objectives of the labour movement (McQueen 1986; Curthoys \& Markus 1978). ${ }^{4}$ The nascent racism of the late $19^{\text {th }}$ and early $20^{\text {th }}$ centuries was nowhere better expressed than by Sir Henry Parkes, one of the leaders of Federation and architects of the 'White Australia' policy, in a speech to the NSW Parliament:

I contend that if this young nation is to maintain the fabric of its liberties unassailed and unimpaired, it cannot admit into its population any element that of necessity must be of an inferior nature and character ... we should not encourage or admit amongst us any class of persons whatever whom we are not prepared to advance to all our franchises, to all our

4. During the $19^{\text {th }}$ century, colonial capitalism was heavily dependent on immigrant labour to facilitate capital accumulation. It was the economic competition, implicit in these policies of growth, which generated fear and exclusion of outside immigrant labour. 
privileges as citizens, and all our social rights, including the right of marriage (quoted in Yarwood \& Knowling 1982).

This candid statement vividly expresses the significance attached to Australian immigration policy in the politics of people building. Price (1974) puts it neatly when he observes that, 'the Chinese were the anvil on which the new young societies were strongly hammering out their national identity'. Mary Willard (1967) confirms this by observing that 'the validity and morality of Australia's policy seems to depend on 'the validity and morality of the principle of nationalism' (p, 206), i.e., of preserving a British Australian nationality. Here we see clearly how history and geography were internally constitutive of a sense of 'peoplehood'.

However, economic competition was not the only reason for the hostility expressed toward non-European immigrants — a point sadly omitted or minimised by recent revisionist historians, ${ }^{5}$ and others critical of the 'black armband' view of history. The Chinese were also - because of their racial differences — despised as being inferior, and viewed as being a threat to social cohesion and unity. Anti-Chinese sentiment was clearly racist and fuelled by stories of illicit sexual relations, implying a threat to racial purity through miscegenation.

The priority given to racial and cultural homogeneity, in particular, the need for 'racial purity' derived largely from $19^{\text {th }}$ century British racial ideology such as biological superiority, inferiority of races, justification of forcible conversions, etc. The Social Darwinism of this period was the motivation, rationale, or rationalisation of a policy of racial exclusion. There was no doubt that these early settlers in subscribing to the ideology of social Darwinism, were also driven by a sense of cultural separatism and cultural supremacy, all of which were confined to the need to preserve 'their inherited and cherished cultural and social homogeneity’ (Levi 1958, 97).

This was achieved with the adoption the IR Act in 1901, embodying the principle of racial exclusion. In fact, the need for a uniform immigration policy in several British colonies prior to Federation constituted one of the main building blocks of Federation in 1901. The legislation on racial exclusion, one of the first acts of the new Commonwealth

5. See, for example Windshutlle (2005), and David Walker (forthcoming) for a well documented rebuttal of Windshuttle's understanding of racism at the time of Federation in his 'Strange Reading: Keith Windshuttle on Race, Asia and White Australia’ in Australian and Historical Studies, 2006. 
Parliament, had as its prime motive the desire to maintain racial and cultural homogeneity. The ideology of racism, characteristic of the British Empire:

was given particular expression in the universal commitment to unity of race as the essential basis for the new nation. White Australia was embraced by all Australians Both indigenous Australians and the populous Asian countries of the region were seen as threatening, racially defined others against whom the new white settlers defined the identity and interests (Brett 2003, 45).

This policy had three key elements: the exclusion of non white immigrants: the desire to encourage continued white immigration i.e., anglo celtic settlers; and thirdly, the belief that Aboriginal people were destined to disappear as a 'race'. After Federation and passage of the IR Act in 1901, this policy came to be later known as the 'White Australia policy'. The economic justification of this racially discriminatory legislation was overlaid by inherent racial antagonisms and the conflation of race, nation, and culture (McQueen 1986). Consequently, White Australia was at the core of an exclusionary model of citizenship on which many of the other pillars of the Australian settlement rested. In this way White Australia as a narrative of political identity was foundational to all other dimensions of the Australian settlement.

This immediately raises the vexed issue of racism $^{6}$ which has baffled and confused not just ordinary folk, but even some eminent scholars! Without entering this minefield let us agree for the present that racism, as an aspect of public policy and community attitudes about 'race' is best understood in terms of the usage of the term 'race' at any given point of time. Accordingly, 'race' as a historically determined social construction becomes manifest as a racial ideology in the domain of socio-political action in a variety of ways, i.e., in terms of the social meanings attached to racialised groups. Racism as an ideology operates in two main ways - as 'old racism', referring to inequalities, discrimination, and domination; and 'new racism in terms of exclusion and differentiation. ${ }^{7}$

From the earliest days racial categorization in Australia was seen as a process by which the 'other' was constructed. At the time of Federation the 'other' was identified in generic terms as the 'yellow peril' - a shorthand way of characterizing a 'generic Asia' (Walker

6. See Jayasuriya (1999, 2002b); Jupp (2002) and Markus (2001) for an overview of racism in the Australian context.

7. See Wievorka (1994) for this distinction on the grounds of two logics of racism - the logic of inferiorization vs. differentiation. The later is linked to unity and diversity. See Jayasuriya (2002b) for its application to Australian racism. 
1999 - not just the mongoloid peoples of South and East Asia. There is no doubt that the idea of a 'White Australia', representing a fear that Asians will destroy Australian national ideals, the invasion narrative, constituted for the greater part of the $20^{\text {th }}$ century, the 'absolute orthodoxy of national existence'. In short, the sense of 'being Australian' was cast in terms of the Asian - 'Other' - and an Australian identity was cast as an independent 'Australian Briton', or, a member of New Britannia. This was clearly what was driving Deakin and others of the time of Federation in promoting a White Australia policy.

While this racial ideology, associated with White Australia, acquired emblematic significance in portraying national identity, it also represented a 'whitening' of Australia, and the erection of 'The Great White Wall' (Price 1974). This, in turn, created an 'anxious nation, ${ }^{8}$ with a deep sense of national insecurity. This sense of unease arose from 'the Australian dilemma' - the irreconcilability of Australia’s history and geography - a European white outpost awkwardly situated among hordes of 'aliens' on it s doorstep - the proverbial 'yellow peril'. Despite the valiant but misguided attempts of some revisionist historians, notably Windshuttle (2005), to sanitize the legacy of a 'White Australia', there is no doubt that the legacy of White Australia continues to be central and critical to understanding not just the Australian-Asian connection, but also the very framing of Australian citizenship.

\section{The Deakin Legacy and Australian Nationalism}

During this early phase of the making of Australia, Alfred Deakin, one of the architects of the White Australia policy and three times Prime Minister of the newly established Commonwealth of Australia, stands out as an influential and powerful leader who had a lasting impact on the formative years of Australian nationhood (Murdoch 1923; La Nauze 1965). Deakin was a man of ideas, and a middle class liberal intellectual of the late $19^{\text {th }}$ century; he was a product of the British imperial/colonial tradition, and someone who proudly wore on his sleeve the qualities of the British Enlightenment.

8. The term 'Anxious Nation'; originating from David Walker’s (1999) pathfinding study of Australian Asian relations 1850-1936, captures the essence of the Australian dilemma. 
But, like many others in English speaking countries, he was most profoundly influenced by the writings of Charles Henry Pearson, ${ }^{9}$ in particular, his seminal text, National life and Character; A Forecast, 1894. Pearson was a liberal European intellectual who, in emigrating from Britain to Australia in the late $19^{\text {th }}$ century, 'surrendered much of this elitist, cosmopolitan, and individualist beliefs, and associated himself with the new movements and sensibilities appearing in the Australian culture' of the late $19^{\text {th }}$ century (Meaney 1995).

Deakin, in seeking an intellectual and moral justification of the policies of racial exclusion which he championed as a leading political figure, leaned heavily on Pearson. As Manning Clark (1985) notes, racial superiority was a central theme of the early Commonwealth, and for Deakin and others at that time, this was intimately connected with the 'invasion narrative' which made Asia 'the spectre haunting the Australian imagination' (Meaney 1995, 175). This also instilled an abiding race patriotism which was largely in terms of the nascent Australian nationalism - the need to defend the white race and western values as the essence of a British Australian national consciousness.

Accordingly, 'national homogeneity', that is, 'the binding together of people who are of the same race or who inhabit in the same country, was central to the idea of nationhood of Pearson and his contemporaries. For Deakin as an 'Imperial Federalist', 'national homogeneity' was also bound to safeguarding a 'white British Australia'. No wonder that Deakin in defending White Australia leant heavily on the ideas of his friend and mentor, Pearson, by arguing that promoting a White Australia' was an 'instinct of self preservation', and adding that 'it is nothing less than national manhood, the national character and the national future that are at stake' (Deakin quoted in Meaney 1995, 175).

This sense of Australian nationalism was built around the pride in the achievements of pre-Federation colonial Australians. ${ }^{10}$ In the broad classification of types of nationalism, Australian nationalism was mainly constructed as an 'ethno-nationalism', where the nation is primarily conceived in terms of shared ethnicity and language (Pitty \& Leach 2004). Yet, Deakin's sense of nationalism was firmly based on human liberal and

9. See Treganza (19678) for an account of the life of Pearson; also Walker (1999).

10. From the late $19^{\text {th }}$ century Australian nationalism was associated with the Australian Natives Association (ANA) established in Melbourne in 1871. The motto of the ANA was 'Advance Australia', and membership was restricted to 'native Australians, i.e., colonial born Australians. 
democratic values, and a tacit endorsement of the fundamental dignity of the human personality regardless of race and colour. However, at the same time it is clear that Deakin's nationalism also entailed a sense of 'civic identity, ${ }^{11}$ as it relates to his strong commitment to a liberal political citizenship, of rights and obligations (Brett 2003). Deakin who greeted his fellow countrymen at Federation as 'citizens of the new born Commonwealth' was one who steadfastly argued for the first time in Australian history for ‘the possession of a common political citizenship’ as a hallmark of being Australian. But as Chesterman and Galligan (2000) argue, the establishment of an Australian citizenship, though not spelt out in the 1901 Constitution, was at the heart of Australian politics at the time of Federation.

Yet, this sense of citizenship was tinged with more than a whiff of illiberal politics. This pertains to what Louis Hartz (1964) refers to as the paradox of equality, viz., equality for the 'white' man but denied for the 'coloured', especially the Aboriginal peoples, It also underlined the fact that the polity was illiberal in that it excluded those who were denied membership on the grounds of 'race' or colour. And the crucial point here is the way tin which a civic citizenship depends on a 'prior' exclusionary constitution of the members of the political community.

For all that, Deakin surely remains an intriguing political figure difficult to label or type cast. For instance, in the realm of politics, he straddled protectionist thinking with state intervention as in the endorsement of the famous Higgins judgment. Importantly, he stood out as an enlightened liberal democrat who was deeply committed to the ideas of a liberal political citizenship as a fundamental principle of the Australian polity. Above all, Deakin was a political pragmatist par excellence. If Benthamite utilitarianism was the uniquely Australian political ideology’ (Collins 1985), Deakin was probably one of its first and most astute exponents.

Deakin’s pragmatism was clearly evident in how Deakin as an avowed Imperialist Federalist, but an 'Australian Briton', dealt with objections from the Imperial government against a policy of exclusion on the grounds of race or colour, which they felt would be offensive to fellow British subjects of the Empire and other friendly powers, in particular

11 As Carter (1998) points out, 'civic identity means that the nation state requires citizens to work with its legal, social, and political institutions' (pp. 23-24). But, with Deakin, this of course sits somewhat uneasily alongside the dominate theme of an 'ethno-nationalism', privileging Britishness. 
Japan. Deakin's intervention on this issue saved the government by arguing for the Dictation Test (the Natal solution requiring competence in a European language) as a ways of reconciling Australian ideals and imperial obligations.

But in Deakin the politician, we also see how history and geography are played out. Ironically, despite references to the 'Yellow Peril', being a threat to 'Caucasian civilization creeds and politics'. Deakin, who understood India as a British imperialist in the late $19^{\text {th }}$ century, had a particular fascination with India and Oriental mysticism. He wrote two books on the Indian sub continent, and one of these was entitled: Irrigated India (Deakin 1893). This, as Walker (2002) notes, confirmed Deakin's reputation as a keen student both of Indian religions and the British Raj'. Deakin, as a pragmatist, considered that there could be 'considerable mutual benefit in closer trading links' with India, and was even 'prepared to make a case for the importation of Hindu workers, if “coloured” labour should prove indispensable to Northern development' (Walker 2002, 22) in Australia. If this was not just another instance of Deakin being a Benthamite utilitarian, not always constrained by principles, was it something which grew out of his long standing interest in theosophy?

There is no doubt that Deakin's spiritual quest which led him from 'Christianity to free thought, to spiritualism and theosophy' (Walker 1999, 23), always remained a potent influence on this thinking about life and society. This was partly reflected in another remarkable book, Temple and the Tomb (Deakin 1893), one on Buddhism and Indian religions written after visiting India and Ceylon. Even by today's standards this reveals a sensitive and deep intellectual grasp of Buddhism; even a willingness to critique the institutional practices of Buddhism in countries such as India and Ceylon which he visited. Indeed, Deakin, the intellectual, led two different lives: that of mundane Victorian politics by day and an inner spiritual life, even as an 'esoteric Buddhist' by night. ${ }^{12}$

Clearly, Deakin as a moderate Liberal was 'not consciously sectarian (Brett 2003, 43), and could not be seen as a militant Protestant. It is also unlikely he would have endorsed the popular view of the times that white superiority also meant the religious superiority of Christianity (Collin \& Henry 1993). According to his friend and biographer, Walter Murdoch, Deakin’s 'religious faith lay at the foundation of his being' (Murdoch, 1923,

12. See Al Gabbay (1992), and Roe (1986) for details of Deakin's interest in eastern religions. See also Croucher (1988) and Carey (2002). 
306). What Deakin detested was not religion itself, but 'priestcraft and dogma and intolerance' (Deakin 1880, quoted in Roe (1986, 34). It is, indeed, a moot point on how far being a ‘Christian nation’ was an element of his sense of Australian nationalism.

Deakin was a truly 'remarkable figure in Australian politics', and an intellectual in politics, who while being a utilitarian pragmatist did not shy away from ideas. Certainly his religious dimension clearly shows that he was gifted with 'an enquiring mind, seeking to embrace truth where he found it' (Brett. 2003, 42). He was a complex personality, as evident in the complementary and even competing political discourses that he was able to straddle. Indeed, it would seem that the history and geography dilemma posed a personal dilemma for a political figure such as Deakin who often espoused contradictory and baffling stands

\section{The Legacy of a White Australia and the Growing Asian Consciousness}

The practice of White Australia - 1901-1970

Against this background for over six decades the White Australia policy dominated — in principle and practice - was one of three pillars of Australian capitalism, the other two being the arbitration system and tariff protection. This was the 'Australian settlement' sometimes known as the 'Deakin Settlement' - which began to be dismantled only in the Hawke and Keating era (1983-1993) and completed under Howard in 2005. Likewise, Australia's defence policy and external relations were firmly impregnated as a corollary to the White Australia policy. The policies of defence and foreign affairs were largely governed by a 'fear of Asia’ which ‘was deeply ingrained’ (Millar 1978, 274).

Japan certainly loomed large in the thinking of W.M. Hughes - Prime Minister of Australia from 1915 to 1923 - who is remembered as the classic symbol and exponent of Australian national and racial consciousness. In his vigorous opposition to Japan's proposal that the League of Nations in 1919 should affirm the principle of equality in the Covenant, Australia reaffirmed the legacy of a White Australia by gaining acceptance at the League of Nations that the principle of equality did not necessarily confer the right of entry into Australia. Likewise, the White Australia policy was extended to Australia's mandated territories in the Pacific as the Forward defence denying any possibility of Japanese encroachment. For Hughes there was no doubt that 'White Australia policy was the cornerstone of the national edifice' (quoted in Yarwood \& Knowling 1982, 246). 
Indeed, as Hancock (1945) observed, in the 1930s, 'immigration policy was not just a frontier policy, a 'geographical policy of security', but one which contained an element of provocation' $(1945,193)$. These concerns were a logical corollary to the legacy of a 'White Australia'. It was imperative that Australia having become an independent British dominion in 1901 had to work out its own responsibility for national security.

The impact of post-World War II events, especially after the fall of Singapore, however, served to change dramatically the nature and character of Australia as an independent nation. The message was clear: Australia could no longer rely solely on mother England for her defence and security. In considering her policy options for national security, Australia was beginning to realise that her long term interests were no longer governed by considerations of the historic past. This prompted Australia to reconsider traditional approaches to defence and security, and establish more direct links with its regional neighbours, many of whom themselves had broken away from the shackles of colonialism and begun to assert their newly won independence. ${ }^{13}$

But yet again these questions of history and geography were played out in the competing narrative of national and political identity. The more critical questions of domestic policy bearing on Australia's economic interests loomed large in the public agenda and took priority over issues of defence and national security. These considerations - all driven by the invasion narrative and subsumed under the slogan 'populate or perish' — began to play a significant role in steering Australia towards a large-scale immigration program as a part of a conscious population policy. Immigration policy, first in terms of changes to recruitment policies and later in the relation to the philosophy of settlement, was destined to have a profound impact on all facets of Australian society. And as at Federation, the 'peopling' of Australia was at the same time about the politics of Australian identity in the context of the tension between history and geography.

This radical social and demographic transformation due to mass migration meant that Australia ceased to be primarily a British settlement with a distinct preference for British settlers. The post 1945 demographic changes showed the Australian and British-born

13. This was very much the message from the Non Aligned Conference of newly independent Third World nations held in Bandung, Indonesia in 1955. Nehru, Prime Minister of an independent India reminded Australia and New Zealand that they must 'make up their minds what they are. If they decided that they are Asians we will welcome them' (quoted in Shann 1967, 8). 
component of the population was reduced from just over 97 per cent in 1947 to 85 per cent in 1991, and 80.6 per cent in 1996.The first change occurred during the early phase of mass migration when there was some flexibility shown in administering the policy of giving preference to British migrants. This relates particularly to the generous and humanitarian policy of accepting ‘displaced persons’ or refugees from the Baltic countries of war torn Europe. For a variety of reasons, this recruitment policy shift was extended to include other European settlers from Poland, Hungary, Czechoslovakia, and later to Southern European countries, especially Greece and Italy. The relaxation in recruitment policies in the 1960s and 1970s also included the entry of settlers from Turkey and the Near East. ${ }^{14}$

This dramatic shift in traditional immigration policy leading to the increasing acceptance of European settlers was skillfully executed, especially in terms of changes to the ideology of settlement. Perhaps the most significant outcome relating to these new 'waves' of European migrants was that it challenged the orthodoxy of settlement philosophy. This, as previously noted, was strictly cast in terms of 'anglo-conformity', dubbed WASP because newcomers were expected to conform to the values of life styles of White Anglo Saxon Protestants (WASP). This approach to migrant settlers denoted a policy of hard-line assimilationism, i.e., one of total anglo cultural conformity. Interestingly, being Christian was never spelt out in the political rhetoric of assimilationism very likely because of the continuing historic Protestant vs. Catholic sectarian conflicts. The policy of 'total assimilation' was shown to be dysfunctional and for strategic reasons partially modified by a policy known as ‘integration’, and later by an entirely new policy of 'multiculturalism' or cultural pluralism.

This new ideology of multiculturalism, which was more accommodating of cultural differences, originating in the Whitlam era and consolidated in the Fraser era, posited a two stage process of adaptation. The first stage permitted a modest relaxation involving a greater degree of acceptance of the culture and social attitudes and practices of new settlers. This was conditional in that it was subject to the proviso that the newcomers accept the social and political institutions of the host society. This was clearly seen in the popular understanding as a milder and more acceptable form of 'assimilationism'. In

14. This amounted to a liberal interpretation of 'White Australia' as it seemed to assume that Turkey was a European nation. This incidentally was of course a determination long before Turkey was deemed eligible to apply for entry to the European Union! 
practice, these policies of settlement were intended to provide a 'buffer zone', a 'psychic shelter' to facilitate social integration. The expectation was that this would enable newcomers or at least their offspring in the next generation, to move into the second stage of total assimilation. The underlying hidden assumption was, of course, a 'melting pot' in which 'cultural difference' would disappear.

In short, demographically, within a short period of four decades, the entry of new immigrants through several waves of migration - European and non European - has radically changed the image of Australia as a society. Australia is descriptively a multicultural society, i.e., in terms of its social demography it is a culturally diverse plural society. But it remains doubtful whether there has been a corresponding shift normatively, i.e., as a constitutive principle of the nation, or a 'multicultural nation'. As we shall see, this normative multiculturalism has become the central problematic of the new political narrative of national identity in the Howard era from 1996.

\section{Confronting Asia post Whitlam: Asian migration and the new economy}

From the point of view of the Australian-Asian connection in the post World War II period nothing was more significant than the growing opposition in the 1960s to race based immigration which resulted in the formal rescinding of the White Australia policy. Not only was there considerable pressure on governments to remove the moral taint of racism, but equally significant were other influences, domestic and external, which paved the way for the most significant liberalization of immigration entry requirements since 1901. The removal of the masthead of The Bulletin - 'Australia for the White Man' by Donald Horne in 1960 was highly symbolic in that it testified concretely to the growing intellectual disenchantment with the racist ideology of the White Australia policy.

Considering that several critics of the ideology of a White Australia argued that 'homogeneity cannot be equated with whiteness' (Horne 1964, 125), some analysts, e.g., Viviani (1992), have argued that this final act of abolition, stamped a different image of Australia in the Asian region. This is only partially true, for it did not remove from the Australian consciousness, the folk psyche, a cardinal tenet of Australian immigration policies, viz., a latent idea of a predominantly homogenous society and an implicit belief a racial and culturally distinctive anglo-celtic society. The firm belief, despite evidence to the contrary (Jayasuriya \& Kee 1999), that 'non Europeans are inassimilable’ (London 1970, 262), has continued to bedevil Australian society for nearly three decades. 
This new policy mix of profound changes to recruitment and settlement was in for a rough ride. The first indications of a backlash against a policy of non discriminatory immigration, i.e., focused on recruitment, appeared with the fears generated by the intake of the 'boat people', the Vietnamese refugees in the late 1970s. This witnessed a reappearance of racism, reactivating the latent invasion fears of an earlier era, and served to confirm for at least the populous at large, the inherent fears of an 'anxious nation', only to be dampened down in political rhetoric. But, the first major and sustained controversy concerning Asian immigration did not occur till 1984 (Markus \& Ricklefs 1985). Here we see how competing stories of peoplehood came to a central place in post Whitlam Australian politics.

The controversy was ignited by a leading Australian historian Geoffrey Blainey who objected to untenable levels of Asian migration, mostly on the grounds that these new settlers had created cultural ghettoes. These unassimilable new settlers were, it was suggested, a threat to social cohesion and national unity. Blainey, though appearing to critique levels of Asian migration, his hidden agenda, as I have argued elsewhere (Jayasuriya 1985) was an implicit, if not explicit, attack on multiculturalism as a policy strategy which threatens the core values of Australian society; indeed, of 'being Australian'. According to some commentators (Markus \& Ricklefs 1985), this serves to highlight the strong nationalistic streak in Blainey's writings on Australian history. This again points to the competing stories of peoplehood coming to the fore in the post Whitlam era.

The general tenor of Blainey's onslaught on ‘Asian immigration' was repeated more emphatically by John Howard in 1988 as the Opposition Leader Howard not only argued for a reduced intake of Asian immigrants, but also added an important corollary - the need to return to a 'One Australia' which Henderson (1995a) remarked was another way of saying 'One Wollstonecraft' (Howard's Sydney suburb). Once again, we see that Blainey and Howard, in challenging immigration intake levels were using anti Asian immigration as nothing but a code for 'anti multiculturalism' These critics of immigration were more emphatic in attacking the historic shift in thinking about migrant settlement multiculturalism - which had been consolidated in the Fraser era (1975-1983). In fact, Howard's 'One Nation' statement as Leader of the Opposition in 1988 was intended mainly as a rebuttal of multiculturalism in the Fraser Era (Maddox 2005). This, as 
Henderson (1995b) very perceptively remarks, 'the basis of Howard's early opposition to multiculturalism' was mainly because of his avoidance of the recognition of 'difference'. For Howard and many other Liberals, equality meant sameness.

In short, Blainey and Howard were in general agreement that multiculturalism in theory and practice as a form of cultural pluralism was inimical to core liberal values such as equality, and also divisive, i.e., threatening the unity of Australian society and its cultural integrity. These sentiments were again repeated more forcefully and effectively when the 'race' debate was reignited in 1996 by Pauline Hanson in her maiden speech in Parliament (Jayasuriya \& Kee 1999). Hanson's contention that Australia was ‘in danger of being swamped by Asians [who] have their own culture and religion, form ghettos and do not assimilate'. These new settlers, in short, were 'un-Australian', and question the integrity of being Australian. This backlash against immigration policies received considerable popular support even among informed circles, and represented nothing more than a sentimental nostalgia for a forgotten past (Jayasuriya \& Kee 1999). What defines Australia? It is this searching question that harks back to the more fundamental questions of history and geography which are so constitutive of the post Federation period.

Concurrent with migrant policy changes favouring Asian migration domestic and external affairs loomed large in the public agenda and generated a new policy focus in the 1980s and 1990s. This new social, political, and economic perspective was predominantly concerned with matters pertaining to the economy, overseas aid, ${ }^{15}$ defence, and foreign policy. First and foremost, the changing ethos of Australian immigration and uncertainty about its long term implications, was intimately linked to the ongoing transformation of the Australian economy, and highlights the significance of the economic dimension of migration. The changes to the economy were in part driven by the new international division of labour whereby manufacturing industries were being located in the Asia Pacific region. The new economic imperatives arising from the structural changes to the economy, and the consequential social transformations of the post World War II period were linked to the Asian Economic Miracle and the rapid rise of key Asian economies (the Asian Tigers — Japan, Korea, Taiwan, and Singapore).

14. Cotton (2005) refers to Australian aid policy as the 'human and soft power' aspects of the AustralianAsian connection. These, though not examined in this paper, warrant greater scrutiny. See Jayasuriya \& Lee 1994). 
This has radically altered the architecture of the global economy and somewhat ironically, after World War II, Japan, heavily dependent on the resource sector, had replaced Britain as the Australia's leading trading partner ${ }^{16}$. As a result, despite the hiccup of the Asian economic crisis in 1997/98, the Australian economy has become deeply enmeshed in the Asia Pacific region in a range of sectors - trade, education, resource commodities, tourism and investment. The stark reality was that there had been a marked shift of trade away from Europe to the Asia Pacific region. Clearly, this new economic environment has continued to exert a powerful impact on all aspects of Australian social and political life - be it immigration, defence, or foreign policy.

Overall, from an Australian perspective this new economic environment was increasingly being dominated by questions of comparative advantage. This was largely a question of the economic linkage mainly through trade relations with the countries of Asian region. In turn, fuelled by the strategy of comparative advantage, this has given a new impetus to the Australian-Asian connection on both fronts - domestic and external - and has become more popularly known as 'the Asian Engagement' or 'Enmeshment'. In this context, the Garnaut Report (Garnaut 1989) was a pathfinding document, which made several recommendations to facilitate Australia's integration with the region. These were largely measures to equip Australia to successfully engage with Asia in matters of trade, education, etc. In relation to Australian foreign policy, Garnaut observed that from the 1980s there has been 'a large shift towards emphasis on regional issues’ rather than global interests. $^{17}$

The political credit for steering- this 'Asian centredness' rests squarely with the Labor Party. This is despite having been the strongest exponent of the cardinal tenets of a White Australia until the late 1960s. On the domestic front, profound changes to migration policy — recruitment, and settlement — were again spearheaded by Labor in the Whitlam era and subsequently endorsed by the more conservative Coalition parties, subject to some important changes, e.g., settlement policy. Likewise, it was in the Hawke and Keating era that the foundations were laid for the economic integration and the adoption

16. For example, the share of exports to the UK and European countries had declined from about $58 \%$ in 1950 to about $17 \%$ in 2001, and conversely the share of imports from these countries had fallen from $60 \%$ in $1949 / 50$ to $11 \%$ in 2001 .

17. See Cotton (2005), Dalrymple (2003), Goldsworthy (2003), Cotton \& Ravenhill (2002), and Evans (1995) for a detailed analysis of these changes in foreign policy. 
of a regional perspective in defence (the Dibb Report) and external affairs (the Harries Report). Here again, while there has been a measure of bipartisan continuity of policy, there are some sharp differences of principle and practice in the 'spirit and tenor' of the policy implementation strategies (Cotton 2005). For instance, whereas the Howard era has proclaimed that its policies are purely in the 'national interest' — often a code for political interest - Hawke and Keating were more willing to explore and engage with abstract ideas and principles relating to the need to effect changes in the anglo-celtic mindset of Australia such as promoting Asian Studies and a greater 'Asian literacy'. ${ }^{18}$

But, as Dalrymple has rightly noted, 'neither Party embraces an affirmative answer to the question: Is Australia a part of Asia?' (Dalrymple 2003, 108). One of the main differences between Labor and the Coalition Parties has been in the realm of external affairs, particularly as regards their respective policy perspectives - rationale and strategies. Thus, for example, despite the bipartisan consensus on foreign policy, the unease about 'Asian Engagement' was perhaps evident in the difference in emphasis placed by the two main political parties on regional as opposed to global interests in fashioning Australian foreign policy (Cotton 2005). Labor, from the days of Whitlam, has been more prone to pursuing an Asian centred and regionally oriented policies, such as those evident in increasing regional cooperation (e.g., APEC). ${ }^{19}$

Labor, especially under the stewardship of Gareth Evans as Foreign Minister, was decidedly more prone to promoting region-wide multilateralism, and actively sought a regional identity. The motif of defence and foreign policy was that security 'lay in the 'region, not against the region. This was mainly in terms of regional structures such as the ASEAN Regional Forum - ARF - a consultative body of major security players - Japan, China and USA (Dalrymple 2003). In many ways this policy orientation harks back to the first flurry of internationalism in the post World War II period chartered mainly by Dr Evatt, the veteran Labor leader and Foreign Minister in the Chifley government, who was also President of the UN General Assembly.

18. See Ingelson Report (1989) and Lo Bianco Report (1987); also Evans (1995) who characterise Asia in terms of the 'East Asian Hemisphere' or 'constructive engagement with Asia'.

19. APEC, central to Asian Engagement in the Hawke and Keating eras, is a loosely structural groping of countries for trade and economic cooperation. APEC consisted of East Asian countries, NAFTA (i.e., US, Canada and Mexico), New Zealand and Chile. 
Admittedly, Evatt's policy perspectives in this regard evolved against the background of the earlier initiatives such as the Colombo Plan in the Menzies era. By contrast, the Coalition Parties in the Howard era, without excluding or denying the earlier regional initiatives, sought to give defence and external affairs policies a new impress with its push towards bilateralism. This was spelt out in the 1997 and 2003 White Papers (DFAT 1997, 2003) which clearly derided the earlier policy strategies stating that 'we do not have to choose between our history and our geography' (Cotton 2005).

Not surprisingly, Howard and Downer were inclined to place more emphasis on old alliances with Britain and the US (e.g., ANZUS), and more recently by explicitly pursuing an avowedly pro-US policy orientation. This was seen in the Asian region as 'the guarantor of the predominance of the anglo-celtic element in the population' (Dalrymple 2003, 216). This was apparent in Howard's willingness to play the role of 'regional policeman', a sort of 'Deputy Sheriff' for the United States, and be seen as a leading member of the 'Coalition of the Willing' in the Asia Pacific region. The 'Howard Doctrine' - as this policy orientation came to be known - certainly contained a message to Australia's regional partners in Asia that she did not seek to be identified too closely with a regional grouping such as the one in the form of the EAEC promoted by Mahathir.

This policy strategy has, of course, shifted somewhat after Howard's unexpected embrace of the East Asian Summit. Notwithstanding this back flip, in whichever way one explains or rationalizes the more explicitly stated foreign policy orientation, i.e., of being in the 'national interests' etc., the 'Howard Doctrine' as it has been played out over a decade, clearly demonstrates a reaffirmation of the politics of people building (Smith 2001) as a legacy of a 'White Australia'. In the 'Coalition of the Willing' Australia remains identified to others as a 'White' outpost with strong political and cultural links to Australia's western allies (UK and USA). This form of national image reflecting a cultural or ethno-nationalism sits more comfortably with Howard and Downer than the more cosmopolitan, global outlook and civic republican nationalism of the Hawke and Keating eras. What we have here, I suggest, are two competing stories of how in this political narrative Australian citizenship is to be framed, one defined in civic or ethnic terms. $^{20}$

20. See Jayasuriya (2005) for a discussion of citizenship theorizing in the polity of a new pluralism. 


\section{The Australian Dilemma and National Identity}

The foregoing brief overview highlights the different facets of the changing AustralianAsian connection manifest over hundred years from Deakin to Howard. These changing perspectives continue to be framed within the context of the Australian dilemma, of history vs. geography, which Bruce Grant depicts vividly by portraying Australia as a White, Christian, European nation being

stuck like an anchored raft between the Indian and Pacific Oceans detached from the great land mass of ideas in the Northern Hemisphere and set apart from the great American Western Hemisphere (Grant 1983, 20).

Central to grappling with this dilemma in the $21^{\text {st }}$ century, as Dalrymple (2003) and others argue, is the uncertainty surrounding an Australian identity. In fact, Bill Hayden as Foreign Minister in the Hawke government observed perceptively that:

Even Gough Whitlam, when he sent to China in 1971 could not have envisioned the way the contact would force us to bite the bullet on the issues of our identity and our relationships in the Asian context (Hayden 1985: 7).

The question of how we are seen in Asia is clearly related to the way in which we have, wittingly or unwittingly, presented an image of ourselves with a distinctive national stamp. This, I suggest lies fairly and squarely in the realm of domestic politics, and is firmly entrenched in the long arm of history, particularly the events leading to Federation. The 'legendary decade' of the 1890s was deeply embroiled in debates about migration from Asia, and these were central to debates about Federation and creating an Australian identity. But these earlier narratives of political identity though greatly modified as a result of internal and external pressures, nevertheless continues to be revealed in political, social and cultural institutions and in day to day social interactions.

Questions of identity are overwhelmingly bound with the social demographic character of Australian society, in particular the changes that have taken place since World War II. This was first characterised by a 'Europeanization' of the population and followed by a 'more radical cosmopolitanisation with an influx of migrants from Asian countries' (Jones 2002, 110). However, the ongoing debate about immigration is no longer about intake policies, but about the philosophy of settlement. Underlying the 'crisis of identity', following the historic shifts in immigration policy, rests fairly and squarely on the ideology of settlement as multiculturalism. The practice of multiculturalism for over three 
decades has thrown into sharp focus questions of Australian identity which indeed were problematic even before the advent of multiculturalism.

The ideology of multiculturalism, ${ }^{21}$ identified as 'cultural pluralism', has resulted in an 'identity politics'. This has, in short, encountered the proverbial paradox of pluralism the juxtaposition of cultural diversity, alongside the commonalities of a universal citizenship — which confronts the very difference it seeks to avoid or minimize, but also denies 'difference’. Unable to accept 'difference' and accommodate this paradox, opinion leaders and the wider public alarmed with the implications of this ideology of multiculturalism, viewed multiculturalism with considerable concern as positing a new constitutive principle of Australian society, which seriously alters the traditional way of 'imagining Australia'. This was, as noted, primarily as an anglo-celtic nation - a White, European, Christian nation with a strong British inheritance.

The disturbing question posed by the critics of multiculturalism, including Blainey, Howard, and Hanson, was whether a diverse and plural society - a mixed nation - was a threat to national unity and cohesion, especially to the traditional sense of an 'Australian identity', the Australian Australia' which had replaced a 'British Australia' of the Deakin era (Wilton and Bosworth 1984). The objections to multiculturalism heavily tinged with anti Asian sentiments from Blainey to Hanson were couched in a language of public discourse markedly different from the discarded 'old racism' of the $19^{\text {th }}$ century. This, in fact, importantly, denotes a different type of racism - a 'new racism' (Jayasuriya 1999, 2002b), expressed predominantly in terms of the logic of differentiation and exclusion rather than on the discredited logic of inferiority/superiority based on biological racism (i.e., 'race' as being linked to biological differences). For 'new racism' it is the threat to the cultural integrity of the majority/dominant groups posed by newcomers of other cultures which is of prime concern

It is this link between national identity and exclusion which is central to 'new racism'. In other words, nationalism is no longer a matter of white or racial superiority but one of 'cultural uniqueness'. The Hansonites' plea for 'cultural distinctiveness' was not directly linked to a cultural cringe associated with the Empire or the 'race patriotism' of the late $19^{\text {th }}$ century, but to core cultural values. Once again, this sense of exclusion was markedly

21. See Jayasuriya (2003) for an overview of multiculturalism as an ideology of settlement. 
evident recently on the Cronulla Beach, and vividly expressed by the cryptic slogan presented as a conflict between those who 'flew here' and those who 'grew here'. In other words, the aliens, the culturally different, i.e., those who were seen not to subscribe to core cultural values, were regarded as not belonging - the excluded ones. As Husband has pointed out, 'the ideas of nation and nationality have provided the language which has allowed for a coded vicarious discussion of races' (Husband 1987, 321). This conflation of race, nation, and culture is highly reminiscent of the legacy of White Australia and canvassing a cultural homogeneity as a basis of unity.

This draws pointed attention to the fact that in dealing with the Australian-Asian connection means inescapably understanding how this emerges out of a citizenship framing the boundaries of the political nation (Jayasuriya 2004). On this question of national identity and multiculturalism, there are two main lines of thinking evident in the Australian multicultural discourse. One approach is in terms of affirming what the Fitzgerald Report (1988) labeled a 'Commitment to Australia'. Fitzgerald, and subsequently, the National Agenda policy document (1989) argued that national identity associated with the multicultural nation rests in the political nation. Thus Fitzgerald described multiculturalism as referring to the values derived from a liberal political culture such as equality, exercise of basic freedoms, mutual tolerance, rule of law, etc. This of course, consists in endorsing the democratic principles associated with a British inheritance, of a political liberal culture.

In short, democracy and equality were regarded as 'essential ingredients in developing a sense of Australian identity' (Jupp 1994, 9), and Keating proceeded to give his imprimatur to this as an acceptable definition of Australian multiculturalism. According to Keating, the basic principles of multiculturalism denote that:

All Australians ... accept the basic principles of Australian society ... [which] include the Constitution and the rule of law, particularly democracy, freedom of speech and religion, English as the national language, equality of the sexes and tolerance (Keating 2000, 262)

At the same time, Keating was emphatic in linking as sense of national identity and Australian patriotism to the multicultural banner by stating that 'the first loyalty of all who make Australia home must be to Australia’ (p. 262). This clearly envisaged replacing a sense of 'British Australia' with a specifically defined sense of an 'Australian Australia'. The latter however had produced very different and often conflicting answers 
(Meaney 1995). One dominant answer was in terms of the qualities and attributes of the political nation of political citizenship which Keating argued was distinctive of multiculturalism. Another was to strengthen this perspective of a normative multiculturalism by identifying what Australians hold in common as defining events of the national story, such as the Eureka Legend or the 'Bush Legend'. ${ }^{22}$ In fact, Labor leaders like Dr Evatt and Whitlam have shown a clear preference in listing the Eureka story $^{23}$ as 'a central legend of Australian nationalism ... symbolic of democracy, freedom, republicanism and multiculturalism' (Duncan et al. 2002, 24-25).

The other dominant approach to characterizing national identity and multiculturalism is associated mainly with Howard who views the national character of a 'multicultural nation' as being embedded in the cultural nation., that is, terms of 'core cultural values'. Ironically, this prioritizing of 'culture' has turned on its head the very grounds on which multiculturalism was rejected by its critics, including Howard (Jayasuriya 2003, 2004). The need a 'return to core anglo-celtic culture' which was also the essence of One Nation's insistence on a historic pact was strongly endorsed by Howard when he embraced the ' $m$ ' word. This was on the explicit understanding of the implications of the 'm' word for national identity.

Howard argued forcibly that unlike other versions of multiculturalism, 'Australian multiculturalism' (branded by Howard) was linked 'a common culture ... [or to] the symbols we hold dear as Australians and the beliefs that we have about what it is to be an Australian' (Howard 1997, quoted in Brett 2003, 195). But, the core values were never spelt out except vague references to the feelings and attitudes associated with 'the spirit of the people', the zeitgeist. This includes in particular reference to Gallipoli, and also to such qualities as mateship and fairgo. ${ }^{24}$ These found expression in Howard's failed Preamble to the Constitution drafted by the likes of Blainey and Murray. This was the only explicit attempt made so far to portray a vision of a shared national identity cast in value terms as being fundamental to the preservation of unity and social cohesion.

22. See Meaney (1995) who examines the multicultural discourse in relation to national unity and identity.

23. See Butler (2003) and Wright (2004) on the Eureka Legend.

24. Dixon (1999) who falls within the ideological left as a feminist historian adopts the Howard/Blainey conservative views on an Australians identity and explicitly refers to the need to reassert an anglo-cetic culture as an essential condition of solidarity and belongingness. 
The Australian values debate, in the context of the Australian-Asian connection, is also of special interest in that an Australian identity may have a bearing on whether, as some, like Evans and Keating suggest, Australia is not just an Anglophone outpost, but also a Christian nation. Marian Maddox in her pathfinding study on the place of religion in Australian politics in the Howard era, cites Linda Doherty in The Herald, who points out that “ "values" for Howard referred not to any religion but meant Christian values' (Maddox 2005, 185) or at least a shorthand for 'religious values' (Maddox 2005). Further confirmation of this comes from Howard's failed appointment of a leading Anglican churchman - Archbishop Peter Hollingsworth as Governor -General, which impacted adversely on Australia being seen as a 'secular democracy'. This trend in some political quarters has to be viewed in the context of Australia's previously pragmatic stance about state and religion. ${ }^{25}$ But with the growing concerns about Islamic fundamentalism and the rise of the religious right this may be severely tested in the foreseeable future.

It is also highly relevant and worth noting that Howard's espousal of core cultural values is remarkably similar to the appeal to 'Asian values' by Asian leaders like Mahathir. As Sen (2005) and others have noted, the championing of Asian values comes mainly from government spokesmen and regional elites of the Asian region. This is primarily intended to emphasize the distinctiveness of the Asians or cultural difference with 'Western values' (Thompson 2001; Dalrymple 2003). In this context, Sen (2005) makes the cautionary comment that the oft made claims that Enlightenment values such as freedom, liberty, and democratic principles, considered central to Western culture are alien to Asian culture, is untenable. There is mounting evidence from the history of ideas that these values are also found in other traditions (Sen 2005; Omvedt 2001).

Furthermore, insofar as the Asian values argument was part of the legitimising strategy of authoritarian Asian regimes (e.g., Singapore and Thailand), in Australia too Howard's 'the politics of reactionary modernization’ (Jayasuriya, K. 1998) was also fortified by resort to 'cultural values' to bolster popular support for Howard's social conservatism and new nationalism. Howard, with his policies of 'border security' and Tampa, cast the 'asylum seekers as a challenge to national identity' (Maddox 2005, 70), and inimical to the core values of Australian society. What is more, Howard repudiated the taunt of

25. In this context, see also the Howard's government blanket rejection of the HREOC Report, Article 18 (HREOC 1995) on endorsing the UN Declaration on the Elimination of All Forms of Intolerance and Discrimination based on Religion or Belief. 
racism leveled at him by portraying the refugees as intimidating the Australian sense of decency!

This serves to confirm Howard's cultural or 'ethno' nationalism and reinforces the Us vs. Them nationalist ideology - the 'them' being clearly defined by the 'outsiders', the marauding refugees, who were battering the Fortress. This nationalist streak is clearly visible in Howard's 1996 Campaign slogan: 'For All of Us'. This was intended to appeal to 'us', that is, those with families considered themselves 'mainstream' and who thought that they had been neglected by attention give to 'Them' - i.e., the Aboriginal people, Asian migrants, single mothers and other 'special interest' (Pitty \& Leach 2004 ) — or 'others'. For Keating the philosophy of Asian Engagement on the other hand, though firmly grounded in the economics of neo liberalism, was framed in terms of an Australian citizenship and a civic republican nationalism. This stood in sharp contrast to Howard's 'ethno nationalism' which was overlaid by a cultural rhetoric and an Australian legend, going back to its British roots, including the monarchy. This shallow anglo-celtic sense of Australian consciousness promoted by Howard is steeped in the 'the Australian way' of the likes of Henry Parkes' One Nation One Destiny, and enshrined in recreating a national story around ANZAS and Gallipoli.

One thing is clear: as long as we debate history and geography we will be arguing about 'who is an Australian?' The formal abandonment of White Australia and the multicultural discourse has not deterred us from 'imagining' Australia away from a 'White Australia (Ang 2002). The emerging Australian identity characterising being Australian demands an inclusionary understanding of Australian citizenship, one which does not exclude those who lacked certain ascriptive characteristics of race, culture, or religion. Paradoxically in this regard, Deakin, more than Howard, may have more to offer for two reasons. One is on the grounds of Deakin's firm commitment to a robust sense of political citizenship and a genuine secular democracy. The other is 'the intellectual openness and commitment to the middle ground associated with Deakinite Liberalism' (Brett 2002, 52), which makes Deakin more receptive to engage with the politics of difference. These qualities, especially political citizenship and acceptance of difference, lend themselves more to the distinctive narrative of the Eureka Legend which laid the ground for a vibrant Australian democracy cutting across many nationalities. For after all, one of the main spokesmen of 
Eureka for the Diggers was Carboni, an Italian, and a 'foreigner'. Indeed as Mark Twain observed, the Eureka Legend remains one of the 'finest things in Australian history' ${ }^{26}$

\section{Conclusion}

In summing up, an overriding theme of this Paper has been that the dynamics of the Australian-Asian connection are deeply grounded in the Australian dilemma, the celebrated tension between history and geography. It is a tension that runs right through how we conceive the Australian political community. As we have endeavoured to show — be they questions of national security, trade relations, or foreign policy — they are all constrained by the Australian dilemma reflecting the questions of what it means to be an Australian. A focus on identity has been largely fuelled by 'a shift in the way we perceive Australia's position in the Asian region' (Dixon 199, 75). As argued, identity in the sense of what it means to 'being an Australian', pertains above all, to questions of equal citizenship and membership of the political community or what Smith (1992) has aptly termed the 'politics of people building'.

Hence, the future directions of the Australian-Asian relationship rests on how we set about the task of creating a sense of Australian nationhood and citizenship in a diverse and plural society. This, as argued, underscores the centrality of immigration policy particularly settlement - in unravelling the tensions between history and geography, or stated differently, of how to cope with Australia's proximity to Asia in dealing with this perplexing question. This is not a question of the 'Asianization' of the country; rather, it one that rests in coming to grips with social and cultural diversity with the framework of a normative multiculturalism - as a constitutive principle of the nation. The institutional response we make to being a 'multicultural nation' holds the key to this problematic. For example, the commanding heights of the society - be they in politics, business, the professions, or even academia - show little signs of being responsive to the new pluralism in Australian society. As I have argued elsewhere, this requires that we reframe the multicultural discourse within the parameters of the political, and not the cultural nation (Jayasuriya 2004). The new Western Australian Charter of Multiculturalism (OMI 2004), based on a notion of 'differentiated citizenship' and a culture of social and political rights and duties, may indeed herald a new course for the languishing multicultural discourse.

26. See Butler (1983); also Wright (2004) which looks at the meaning of Eureka in Australian history. 
Finally, it begins to become more apparent and compelling to recognise that 'Australia's future lay not just in Asia but with Asia' (MacMahon Ball quoted in Rix 1985) it is imperative that we make a more constructive and creative response than in the past in fashioning our 'Asian centredness'. This is not just confined to the realm of politics and economics but more centrally focussed in getting out of being in a cultural cocoon, and able to meaningfully engage with the many cultural traditions in Asia. In this we need to be reminded of the prophetic words of Alfred Deakin over a hundred years ago. In his reflections following his visit to India, Deakin observed wisely in 1893 that:

Today's Australia is full of hope, as Asia of despair. racially, socially, politically and individually far asunder as the poles. Their geographical situation, brining them face to face may yet being them hand to hand, and mind to mind. They have much to teach each other

While commending these wise words to the current Australian political leadership, we might add a footnote to Deakin from Bruce Grant (1983), a former Australian Ambassador to India in his prophetic remark that 'Asia remains the most likely catalyst of Australian civilization’ 


\section{References}

Ang, I. (2002) 'From White Australia to Fortress Australia: The Anxious Nation in the New Century', in L. Jayasuriya, D.Walker \& J. Gothard (eds), Legacies of White Australia. Race Culture and Nation. University of Western Australia Press, Perth.

Blainey, G. (1984) All for Australia. Methuen, Melbourne:.

Brawley, S. (2002) ، "Legacies”. The White Australia Policy and Foreign Affairs', in L. Jayasuriya, D.Walker \& J. Gothard (eds), Legacies of White Australia. Race Culture and Nation. University of Western Australia Press, Perth.

Brawley, S. (1995) The White Peril. Foreign Relations and Asian Immigration to Australia and North America. University of New South Wales Press. Sydney.

Brett, J. (2003) Australian Liberals and the Moral Middle Class: From Alfred Deakin to John Howard. Cambridge University Press, Cambridge.

Bronowski, A. (2003) About Face. Asian Accounts of Australia. Scribe, Carlton.

Butler,R. (1983) Eureka Stockade. Angus \& Robertson, Sydney.

Carter, D. (1998) 'Working with the Past, Working on Future', in R. Nile \& M. Peterson (eds), Becoming Australia. University of Queensland Press, Brisbane.

Chesterman, J. and B. Galligan (2000) Defining Australian Citizenship. Selected Documents. Melbourne University Press, Carlton.

Carey, H, (2002) 'Australian Religious Culture from Federation to the New Pluralism' in L. Jayasuriya, D.Walker \& J. Gothard (eds), Legacies of White Australia. Race Culture and Nation. University of Western Australia Press, Perth.

Clark, M. (1985) Heroes, in S.R. Graubard (ed.), Australia. The Daedalus Symposium. Angus \& Robertson, Sydney.

Collins, H. (1985) 'Political Ideology in Australia: The Distinctiveness of a Benthamite Society', in S.R. Graubard (ed.) Australia. The Daedalus Symposium. Angus \& Robertson, Sydney.

Cotton, J. (2005) ‘Australia and Asian Institutions: Bilateral Preferences and Multilateral Gains' Presented at Workshop on Governance and Regionalism in Asia. Centre for Asian Studies, University Hong Kong, December.

Cotton, J. (ed.) (1997) Seeking Asian Engagement: Australia in World Affairs 1991-1995. Oxford University Press, Melbourne.

Cotton, J. and J. Ravenhill (eds) (2002) The National Interest in a Global Era. Oxford University Press, Melbourne.

Collins, J. and F. Henry (1994) 'Racism, Ethnicity and Immigration', in H. Adelman, A. Bronowski, M. Burstein \& L. Foster (eds), Immigration and Refugee Policy: Australia and Canada Compared, (2 vols). Melbourne University Press, Carlton.

Crook, K.A.W. (1970) ‘Security for Australia?’ James Backhouse Lecture. 
Croucher. P. (1988) History of Buddhism in Australia 1848-1988. University of New South Wales Press, Sydney.

Curthoys, A. and A. Markus (eds) (1978) Who are Our Enemies? Racism and the Australian Working Class. Hale \& Iremonger, Sydney.

Dalrymple, R. (2003) Continental Drift: Australia's Search for a Regional Identity. Ashgate, Aldershot.

D’Cruz, D.V. and W. Steele (eds) (2003) Australia's Ambivalence towards Asia. Monash Asia Institute, Clayton, Victoria.

Deakin, A. (1893) Irrigated India: Australia's View of India and Ceylon, their Irrigation and Agriculture. London; and Temple and Tomb in India. Melville, Midlen and Slade, Melbourne;

Dixon, M. (1999) The Imaginary Australian: Anglo Celts and Identity 1788 to the Present. University of New South Press, Sydney.

Duncan, M., A. Leigh, D. Madden \& P. Tynan (2004) Imagining Australia: Ideas for the Future. Allen \& Unwin, Sydney.

Evans, G. ((1995) Australia in East Asia and the Asia Pacific. Beyond the Looking Glass. AsiaAustralia Institute, Sydney.

Evans, G. and B. Grant (1991) Australia's Foreign Relations in the World of the 1990s. Melbourne University Press, Carlton.

Fitzgerald, S. (1997) Is Australia an Asian Country? Allen \& Unwin, Sydney.

Gabbay, Al (1992) The Mystic Life of Deakin. Cambridge University Press, Cambridge.

Gilbert, H.,-T. Khoo, and J. Lo (eds) (2003)Diaspora: Negotiating Asian-Australia. University of Queensland Press, St Lucia.

Goldsworthy, D. (ed.) (2003) Facing North. A Century of Australasian Engagement. Melbourne University Press, Carlton.

Grant, B. (1983) The Australian Dilemma. Melbourne: McDonald Futura.

Hancock, W. (1930) Australia. E.Benn, London.

Hartz, L. (ed.) (1964) The Founding of New Societies. New York: Harcourt.

Hayden, W. (1985) Australia and Asia: Options and Opportunities. Centre for Asian Studies, University of Sydney.

Henderson, G. (1995a) 'What Howard has to do’. Sydney Morning Herald, January 28.

Henderson, G. (1995b) A Howard Government? Harper Collins, Sydney.

HREOC (Human Rights and Equal Opportunity Commission) (1995)

Hugo, G. (1992) 'Knocking at the Door: Asian Immigration in Australia', Asian and Pacific Migration Journal, 1 (4). 
Husband, C. (1987) 'British Racism', in C. Husband (ed.), Race in Britain: Continuity and Change. $2^{\text {nd }}$ edn. Hutchinson, London.

Jones, G.W. (2002) 'White Australia, national Identity and Population', in L. Jayasuriya, D.Walker \& J. Gothard (eds), Legacies of White Australia. Race Culture and Nation. University of Western Australia Press, Perth

Jayasuriya, K. (1998) 'Understanding Asian Values as a form of Reactionary Modernisation'. Contemporary Politics 4 (1), 77-91. (revised version of article in NIASnytt, 1997)

Jayasuriya, L. (2004) 'The Politics of a New Pluralism: Reframing Citizenship'. Available at: www.socialwork.arts.uwa.au/_data/p[age/33070/politics_of_newpluralism.pdf.of/items/2004 102/000, and at Pandora Archive, NLA, 2004.

Jayasuriya, L. (2003) 'Australian Multiculturalism: Past, Present and Future’. Available at: Http://www.arts.uwa.edu.au/sociWkwww/7.2003

Jayasuriya, L. (2003) 'Politics of a New Pluralism'.

Jayasuriya, L. (2002a) ‘Fin de Siècle Musings’, in L. Jayasuriya, D.Walker \& J. Gothard (eds), Legacies of White Australia. Race Culture and Nation. University of Western Australia Press, Perth.

Jayasuriya, L. (2002b) Understanding Australian Racism’. Australian Universities Quarterly, 25 (1).

Jayasuriya, L. (1999) Racism, Immigration and the Law. Perth: School of Social Work and Social Policy, University of Western Australia.

Jayasuriya, L (1997) Immigration and Multiculturalism in Australia. Perth: School of Social Work and Social Administration, University of Western Australia.

Jayasuriya, L (1984) ‘Blainey’s Real Agenda’. Migrant Action, 7 (2).

Jayasuriya, L. and Kee PooKong (1999) The Asianization of Australia? Some Facts about the Myths. Melbourne University Press, Melbourne.

Jayasuriya, L. and M. Lee (eds) (1994) Social Dimensions of Development. Pardigm Press, Perth.

Jones, G. W. (1997) “Australian Identity”, Racism and Recent Responses to Asian Immigration to Australia, Working Papers on Demography, No. 71. Research School of Social Sciences, Australian National University, Canberra.

Jupp, J. (1998) Immigration. Oxford University Press, Oxford.

Jupp, J. (1994) ‘Identity’, in R. Nile (ed.), Australian Civilization. Oxford University Press, Melbourne.

Keating, P. (2002) Engagement: Australia Faces the Asia Pacific. Macmillan.

La Nauze, J.A. (1965) Alfred Deakin. A Biography, Vol 1. Melbourne University Press, Melbourne.

Levi, W. (1958) Australia's Outlook on Asia. Angus \& Robertson, Sydney.

London, H. I. (1970) Non-White Immigration and the 'White Australia' Policy. New York University Press, New York. 
McCawley and P. Dibb (eds) Australia's External Relations in the 1980s. Croom Helm, London.

Maddox, M. (2005) God under Howard. The Rise of the Religious Right in Australian Politics. Allen \& Unwin, Sydney.

Malouf, D. (1994) 'Identity as Lived Experience. Uniquely Australian'. The Sydney Papers, Spring Issue.

Markus, A. (2001) Race: John Howard and the Remaking of Australia. Allen \& Unwin, Sydney.

Markus, A. and M.C. Ricklefs (1985) Surrender Australia: G. Blainey’ and Australian Immigration. Allen \& Unwin, Sydney.

McGillviray, M. and G. Smith (eds) (1997) Australia and Asia. Oxford University Press.

Millar, T.B. (1978) Australia in Peace and War: External Relations 1788-1977. Australian National University Press, Canberra.

McQueen, H. (1986) A New Britannia: An Argument Concerning the Social Origins of Australian Racialism and Nationalism, (rev. edn). Melbourne: Penguin.

Meaney, N. (1995) 'The End of "White Australia” and Australia's Changing Perceptions of Asia, 1945-1990’. Australian Journal of International Affairs, 49 (2)

Murdoch, W. (1923) Alfred Deakin: A Sketch. Constable, London.

OMI (Office of Multicultural Interests, WA) (2004) The Charter of Multiculturalism. Government of WA, Perth.

Omvedt, G. (2001) ‘The Buddha as a Political Philosopher’. Economics and Political Weekly, Delhi, May 16.

Pearson. C. H. (1894) National life and Character; A Forecast, ( ${ }^{\text {nd }}$ edn). Macmillan, London.

Pitty, R. and M. Leach (2004) 'Australian nationalism and internationalism' in P. Boreham, G.Y. Stokes \& R. Hall (eds), The Politics of Australian Society, 2nd ed.. Pearson, Sydney,

Price, C. (1974) The Great White Walls are Built: Restrictive Immigration to North America and Australasia. Australian National University Press, Canberra

Roe, J. (1986) Beyond Belief: Theosophy in Australia 1879-1939. University of New South Wales Press, Sydney.

Sen, A. (2005) The Argumentative Indian. Farrar, Straus \& Giroux, New York

Shann, K.C. (1967) ‘Our Future as an Asian nation: A Review’, in H.E.W. Roberts (ed.), Our Future as an Asian Nation. University of Western Australia, Adult Education Board, Perth

Smith, R. (2001) 'Citizenship and the Politics of People Building’ Citizenship Studies 5 (1).

Smith, R. (1992) Civic Ideals: Conflicting Views of Citizenship on US History. Yale University Press, New Haven.

Rix, A. (1985) 'MacMahon Ball - A Pioneer in Australia Asia Policy’. Australia in Asia Series, No 3, Griffith University, Brisbane 
Thompson, M. (2001) 'Whatever happened to “Asian Values”?’ Journal of Democracy 12 (4).

Treganza, J. (1968) Professor of Democracy. The Life of Charles Henry Pearson Oxford Don and Australian Radical. Melbourne University Press, Carlton.

Viviani, N (1974) ‘Australia and New Zealand in Asia’. In R. Brissenden \& J. Griffin (eds), Modern Asia. Jacaranda Press, Melbourne.

Walker, D. (1999) Anxious Nation: Australia and the Rise of Asia, 1850-1959. Brisbane: University of Queensland Press.

Walker, D. (2003) 'Afterword’, in D.V. D’Cruz \& W. Steele (eds), Australia’s Ambivalence towards Asia. Monash Asia Institute, Clayton, Victoria.

Wieviorka, M. (1995) The Arena of Racism. Sage, London.

Willard, M. (1967) History of the White Australia Policy to 1940. Melbourne University Press, Carlton.

Wilton, J. and R. Bosworth (1984) Old World and New Australia. Penguin, Sydney.

Windshuttle, K. (2005) The White Australia Policy. Macleary Press, Sydney.

Yarwood, A. T and M. J. Knowling (1982) Race Relations in Australia: A History, Melbourne: Methuen.

Wright, C. (2004) 'Cradle of Democracy or a Small Uprising? Historians Assess the meaning' The Age $3^{\text {rd }}$ December

\section{Reports}

DFAT Department of Foreign Affairs and Trade (1997) 'In the National Interest'. White Paper.

DFAT (2003) ‘Advancing the National Interests’. White Paper.

Dibb Report (1986) Review of Australia's Defence Capabilities. Chair: P. Dibb. AGPS, Canberra.

Fitzgerald Report (1988) Immigration: A Commitment to Australia. Chair: S. Fitzgerald. AGPS, Canberra.

Garnaut Report (1989)) Australia and The Northeast Asian Ascendancy. Chair: R. Garnaut. AGPS, Canberra

Harries Report (1979) Australia and the Third World: Report of the Committee on Australia's Relations with the Third World. Chair: O. Harries. AGPS, Canberra

Ingleson Report (1989) Asia in Higher Education. Chair: J. Ingleson. Asian Studies Council, Commonwealth Department of Education

Lo Bianco Report (1987) National Policy on Languages. Chair: J. Lo Bianco. AGPS, Canberra. 